\title{
SUSTAINABILITY ASSESSMENT METHODS IN OIL SHALE MINE CLOSURE
}

\author{
Sergei Sabanov, Jyri-Rivaldo Pastarus, Julia Shommet
}

Tallinn University of Technology, Department of Mining

5 Ehitajate tee St, Tallinn, 19086, Estonia

E-mail: sergei.sabanov@ttu.ee,pastarus@cc.ttu.ee,julia.shommet@hotmail.com

\begin{abstract}
The post mining processes impacts on the environment, economy and people, whilst there may be positive contributions to the economy and social progress through mining there may also are negative impacts to the environment. The aim of this study is to elaborate sustainability assessment methodologies suitable for mine closure life cycle stage which allows defining hazardous influences on environment, society and economic dimensions, and helps quickly, conveniently and qualitatively solve, operate, find optimum variants for existing problems. The sustainability assessment methods will provides best decisions on the technological and post technological processes of a mining industry and can be used in the exploration, planning, exploitation and closure stages
\end{abstract}

Keywords: sustainable mining, waste management, risk assessment.

\section{Introduction}

The extraction of oil shale is a temporary land use. Once mining has finished the land can be 'recycled' or reused through restoration. In many cases, restoration involves returning the land to its original use. However, this is not always feasible. Through creative restoration planning, oil shale extraction offers the opportunity to improve the environment in and around mine sites or to create new land uses $[1,2,3,4]$. Various processes in oil shale mining industry often become dominating in the most dangerous post-technological process, which can pose a hazard to people, cause economic damage and environmental interventions. Providing of favourable conditions for oil shale mine closure in conformity with technological and ecological safety defines the necessity of elaboration the sustainability assessment methods. The reason is related to absence of suitable criteria, skills and methodology of using oil shale resources that is suitable for all parties. The aim of this study is to elaborate sustainability assessment methodologies suitable for mine closure life cycle stage which allows defining hazardous influences on environment, society and economic dimensions, and helps quickly, conveniently and qualitatively solve, operate, find optimum variants for existing problems and optimize usage of mineral resources. Important tasks are analysing a ground surface longterm stability under usage backfill method and determination opportunities to economic of mining waste management.

\section{Sustainability assessment methods}

Sustainability assessment is a comprehensive, integrated and far-sighted approach to decision making. Its basic demand is that all significant undertakings must make a positive contribution to sustainability. The mining industries worldwide are changing their mining practices by developing and implementing a variety of technologies and mining methods are compatible with the principles of sustainable development. Adoption of the principles of sustainable development by the mining industry comes at a cost and requires major changes to current mining practices. Relating the different approaches to sustainability assessment across disciplines and against the background of the conceptual framework allows us to appraise their relative potentials and limitations. The constraints to scientific operationalisation of sustainability and to its translation into policy measures, which are revealed by this reference system, highlight the necessity for continued integrated systems research $[1,2,3,4]$. 
Closure planning is an activity that continues throughout the life of a mine, starting with conceptual closure plans prior to production, periodic updates throughout the life of the mine, and a final decommissioning plan. At most mines, progressive reclamation over the life of the mine is used to reduce the reclamation burden at closure.

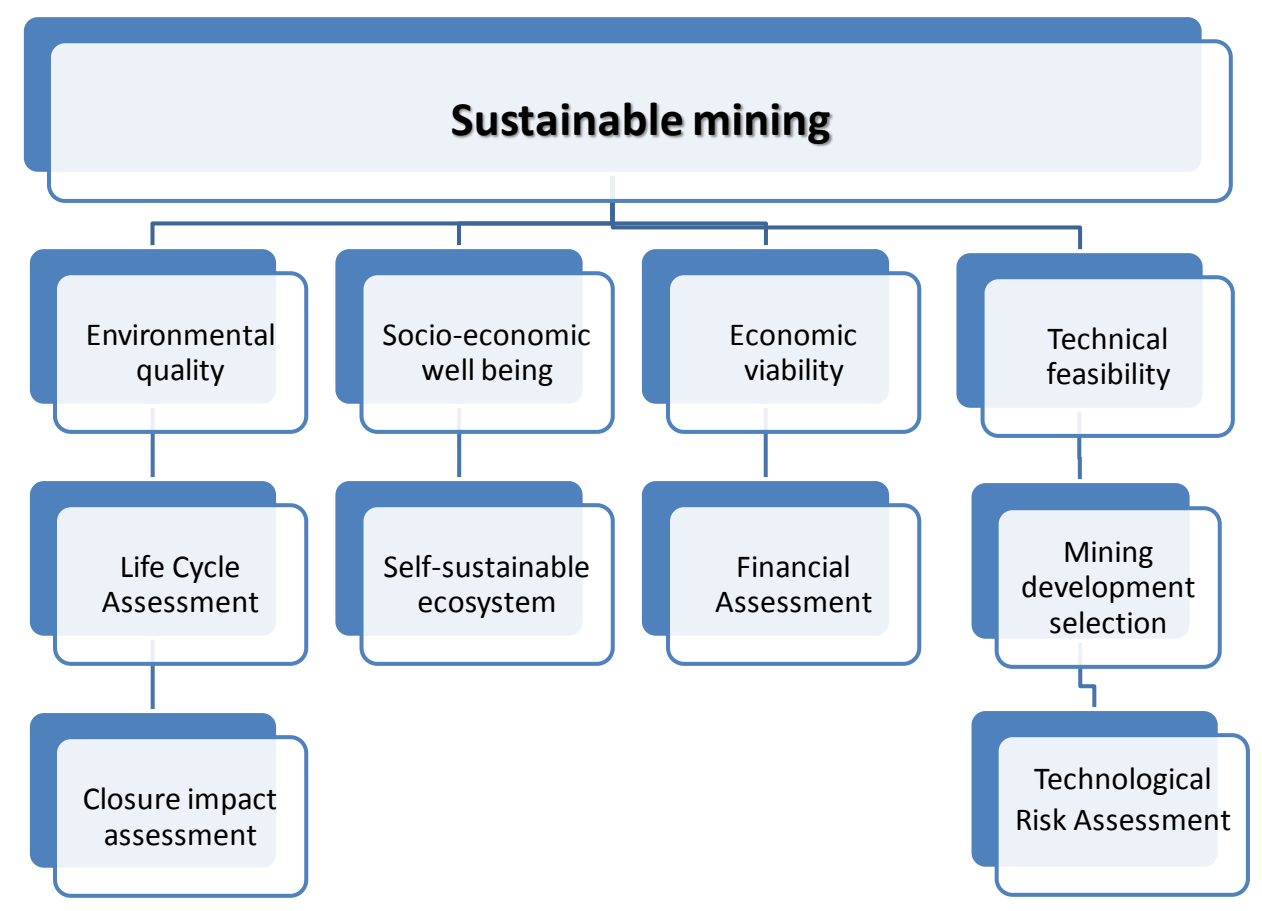

Fig.1. Sustainability assessment methods

\section{Environmental Quality}

The environmental impacts associated with oil shale preparation and productions are subsequently variable, as the mining methods used to extract oil shale by open and underground methods result in different environmental impacts [7]. The objective is to include all activities that usually take place around a mining site. In this study, the Life Cycle Assessment (LCA) tool is used to analyze and assess the environmental impact of oil shale mining. The inputs and outputs identified for all the technological chains of underground and open mining methods are under investigation $[7,8]$.

This part contributes in preventing undesired collapses and hazards related to them, emission to atmosphere and aquifer. Conditions for sustainable mining in densely populated regions allows changing large areas of mined areas to suitable farmland or building areas. Mine-water could be used for drinking water after self-cleaning.

\section{Economical viability}

Economic sustainability is clearly identified information, integration, and participation as key building blocks to help countries achieve development that recognises these interdependent pillars. It emphasises that in sustainable development everyone is a user and provider of information. It stresses the need to change from old sector-centred ways of doing business to new approaches that involve cross-sectored co-ordination and the integration of environmental and social concerns into all development processes. Furthermore, broad public participation in decision making is a fundamental prerequisite for achieving sustainable development $[1,4]$. 


\section{Technical feasibility}

Technical feasibility is one of the important parts of the sustainability assessment methods. Risk assessment techniques defined in its broadest sense, deals with the probability of any adverse event [6]. Various types of risk considered in the mine closure include the engineering risk, human health risk and ecological risk. Risk assessment is the process of deciding whether the existing risks are tolerable and risk control measures are adequate. It incorporates the phases of risk analysis and risk evaluation.

\section{Socio-economical well-being}

This part provides diminishes the risk of accidents and casualties in mining, low emissions technologies. Socio-efficiency describes the relation between a firm's value added and its social impact. Both eco-efficiency and socio-efficiency are concerned primarily with increasing economic sustainability. The business case alone will not be sufficient to realise sustainable development.

Mine closure is the period of time when the extracting activities of a mine have ceased, and final decommissioning and mine reclamation are being completed. It is generally associated with reduced employment levels, which can have a significant negative impact on local economies. It is also the period when the majority of mine reclamation is completed, making the land safe and useful again [2,3,13].

\section{The methodology techniques}

- Designing mine closure systems for surface and underground mines

- Determining the elements for mine closure infrastructure

- Integrating life-cycle models of oil shale and energy commodities to describe global geologic occurrences, genetic processes, present and future uses, recycling potential, possible substitutions, disposal strategies, and associated environmental effects. Investigation of bedrock hydrological and mineral-related elements, slope stability, soil formation, and sediment transport and deposition is aid in understanding the structure and function of natural ecosystems

- Assessing geologic and geotechnical risks influencing on subsurface displacement and subsidence

- Defining technogenic deformation processes by geotechnical monitoring

- Identification of the opportunities to economic mining waste management

Predicting the long-term stability behaviour of underground oil shale mines and the attenuation or degradation of rock wastes requires an improved understanding of the rheological processes controlling the changes of physical-mechanical properties. In backfill technologies past fill of underground goaf (using mixture of limestone rock and ash from power plant) are preferred. Effect of backfilling will serve for minimization of surface movement; improvement of safety in mining (high rock pressure, water outflow, etc.; facilitation of mining operations; increase of extraction ratio; binding mobile elements). The methodology helps revealing behaviour of backfill material in-situ conditions and definition physics-mechanical characteristics and rheological properties for various structures of backfill components. Risk estimation will be used for calculation probability of a ground surface subsidence and displacement. Particular attention must go to issues of waste production and storage, old mining waste landfills, waste handling procedures, entrepreneurship development and the legal framework for waste management. Environmental and social assessment tools should be combined to enable a transition to integrated impact assessment. This will be used for future projects consultation with the community to identify local concerns. 


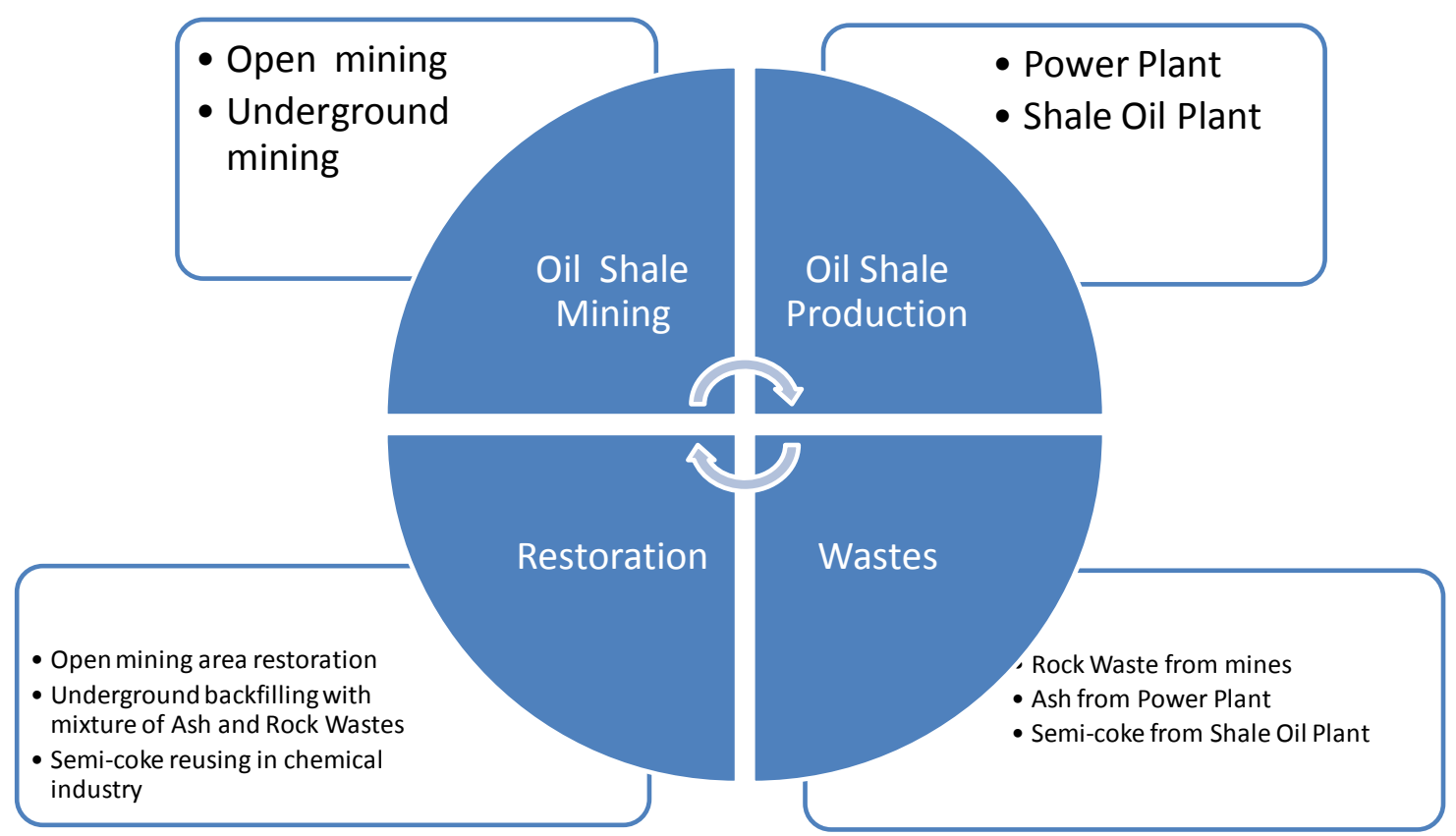

Fig. 2. Shale Life Cycle stages alternatives

\section{Conclusions}

The sustainability assessment methods can be used for different purposes and at different levels: as a basis for decision-making when selecting among different remedial actions for a mined out area within time and financial restraints; to relate ground surface subsidence risk levels to acceptable risk levels established by the society for other activities, predicting the long-term hydrologic behaviour of aquifers and aquitards and the attenuation or degradation of toxic wastes, methodologies on management of mining wastes. The methods is able to give opportunity to find better way for mine closure planning in according with environmental performances and socio-economical well-being.

\section{Bibliography}

1. Barbara Becker. Sustainability Assessment: A Review of Values, Concepts, and Methodological Approaches. Consultative Group of International Agricultural Research. 1997, Issues in agriculture10.

2. Eijkern, Sander, DiPiazza, S., SAM Corporate Sustainability Assessment. The sustainability year book 2009.

3. Gibson, Robert B. Sustainability-based assessment criteria and associated frameworks for evaluations and decisions: theory, practice and implications for the Mackenzie Gas Project Review, a report commissioned by the Joint Review Panel for the Mackenzie Gas Project, final report 26 January 2006, 67pp.

4. Gibson, Robert B., Sustainability Assessment: criteria and processes, with Selma Hassan, Susan Holtz, James Tansey and Graham Whitelaw (London: Earthscan, 2005), 254pp.

5. Jaber, J.O., Probert, S.D., 1999. Environmental-impact assessment for the proposed oil-shale integrated trigeneration plant. Applied energy 62, pp. 169-209

6. Sabanov, S. (2009). Risk assessment methodology in oil shale mining. The Reading Matrix Inc. Irvine, CA, USA (Toim.). Proceedings of the Eighteenth International Symposium on Mine Planning and Equipment Selection (MPES 2009) and the Eleventh International Symposium on Environmental Issues and Waste Management in Energy and Mineral Production (SWEMP 2009) (711 - 718). Reading Matrix Inc USA

7. Sabanov, Sergei ; Šommet, Julia; Milaševski, Irena; Bashkite, Viktoria; Gulevitš, Julia; Beldjaev, Viktor; Robam, Karin (2010). Sustainability assessment methods for developing advanced mining technologies. In: 9th International Symposium "Topical problems in the field of electrical and power engineering. Doctoral school of energy and geotechnology". II : Pärnu, Estonia, 14.06.-19.06.2010:, 2010, 69 - 74.

8. Sabanov, S.; Milashevski, I.; Beldjaev, V. (2010). Sustainable Mining Under Usage Modern Machines in Estonian Oil Shales Mines. In: Theory and Practice of Geomechanics for Effectiveness. The Mining Production and the construction: The 4th International Geomechanics Conference, Bulgaria, 3-6 June 2010. , 2010, $551-556$. 
9. Sabanov, S. (2009). Sustainable development of oil shale industry under support of ecological viability of mineral resources. 8th International Symposium, September 19-23, 2009, Tallinn, Estonia. "Resource Reproducing, Low-wasted and Environmentally Protecting Technologies of Development of the Earth Interior" Proceedings of Tallinn: Department of Mining TUT; Russian University of People Friendship

10. Sabanov, S (2009). Sustainability assessment of Estonian oil shale mining using advanced technology. In: 29th Oil Shale Symposium, USA, Colorado, October 19-23, 2009. Colorado School of Mines and Colorado Energy Research Institute:, 2009.

11. Fourie, A., Brent A.C. 2006. A project-based Mine Closure Model (MCM) for sustainable asset Life Cycle Management. Journal of Cleaner Production 14 (2006) 1085e1095

12. FREDERIC CLARIDGE, SOLOMON PHIRI And WES FUNK PLANNING FOR CLOSURE COPPERBELT ENVIRONMENT PROJECT, ZAMBIA.

13. Laurence David. Classification of Risk Factors associated with mine closure. School of Mining Engineering, UNSW.

14. Laurence David. Optimisation of the mine closure process Journal of Cleaner Production Volume 14, Issues 3-4, 2006, Pages 285-298. 